\title{
Evaluasi 3D Texturing Process Pada Bentuk Dinding Bangunan Bersejarah Candi Cetho
}

\author{
Dimas Setiawan \\ Universitas PGRI Madiun \\ Program Studi Sistem Informasi \\ dimas.setiawan@unipma.ac.id
}

\begin{abstract}
Abstrak
Pemanfaatan teknologi dapat dimanfaatkan untuk membantu pemerintah dalam upaya pelestarian budaya, trend baru dalam melakukan proses rekonstruksi yang biasa dilakukan adalah dengan melakukan Pemodelan 3D dengan menggunakan teknik scan dan fotogrametri. Pemodelan menggunakan teknik polygonal modeling menghasilkan produk model 3D dari candi cetho, namun proses pemberian teksturnya perlu melewati beberapa uji coba sehingga mampu menghasilkan produk yang menyerupai aslinya. Pemodelan 3D candi cetho dengan procedural texture didapatkan prosentase Sebanyak 72 \% Tidak mirip,20 \% mirip, dan 6\% sangat Tidak mirip sedangkan Untuk Model 3D candi cetho dengan files textures didapatkan prosentase Sebanyak 84 \% mirip dan 16 \% sangat mirip.
\end{abstract}

Kata kunci : Texturing, 3D Modeling, candi Cetho, Procedural textures, Files Textures.

\section{PENDAHULUAN}

$\begin{array}{cc}\text { Setiawan (2017) } & \text { menyatakan } \\ \text { pemanfaatan teknologi } & \text { 3D dapat }\end{array}$ digunakan untuk membantu program pemerintah dalam upaya pelestarian cagar budaya, hal ini juga diatur pada pasal 53 ayat (4) UU No.11 tahun 2010 tentang pelestarian cagar budaya yang berisikan Pelestarian Cagar Budaya harus didukung oleh kegiatan pendokumentasian sebelum dilakukan kegiatan yang dapat menyebabkan terjadinya perubahan keasliannya.

Candi Cetho merupakan salah satu bentuk bangunan Cagar Budaya yang letaknya berada di dusun Cetho, desa Gumeng, kecamatan Jenawi, kabupaten Karanganyar. Candi ini terletak di sekitar lereng gunung lawu dengan ketinggian $1.400 \mathrm{mdpl}$. Akses jalan yang menanjak, dan letaknya yang berada di lereng gunung membuat banyak masyarakat umum kurang mengenal obyek cagar budaya ini. Penyebaran hasil dokumentasi berupa gambar 2D yang tersebar dunia maya secara keseluruhan tidak mampu memperkenalkan bentuk bangunan utama Candi Cetho secara keseluruhan.

Sehingga diperlukan alternatif baru untuk memperkenalkan obyek candi dengan mengembangkan pendokumentasian dalam bentuk model 3D. model 3D memiliki banyak fungsi. Selain untuk memberikan gambaran 3D dari sebuah arsip gambar maupun hanya catatan sejarah. Selain itu model 3D dapat difungsikan sebagai alat peraga guna mewakili objek aslinya yang tinggal sejarah. (Hendy,2015)

Penelitian tentang analisa dan perancangan 3D candi Cetho yang dilakukan oleh dimas setiawan, pemodelan menggunakan metode polygonal modeling dengan memanfaatkan proses pembuatan gambar referensi dari sisi samping dan depan dari candi cetho. Dari hasil pemodelan produk 3D candi cetho tanpa tekstur dihasilkan sebuah produk 3D dengan jumlah vertexs sebanyak 2832, edges sebanyak 5361, dan faces sebanyak 2547.

Hasil dari pemodelan ini masih diperlukan tindak lanjut dengan 3D texturing Process, dengan adanya proses penteksturan diharapkan dapat membuat produk dari candi cetho dapat menyerupai obyek aslinya.

\section{KAJIAN PUSTAKA}

3D modelling adalah hasil dari representasi dari proses secara matematika yang membentuk objek 3D. Hasil dari proses tersebut adalah apa yang sekarang ini disebut dengan 3D model atau 3D Mesh.(Prasetyanto,2014).

Evaluasi 3D Texturing Process... (Dimas Setiawan) | 7 
William Vaughan (dalam ridwan, 2015) membagi 3D modelling menjadi dua kelompok berdasarkan carapembuatannya. Melalui aspek produksi, konstruksi, dan klasifikasi evaluasi model 3D terbagi menjadi 2 pokok yakni objek Hard Surface (NonOrganic) dan organic. Digital atau biasa disebut Digital Modeling adalah sebuah Proses Pemodelan secara digital dari bentuk nyata maupun fiktif yang direkayasa dengan menggunakan perangkat lunak khusus dengan merepresentasikannya melalui sebuah bentuk objek 3D. (Ridwan,2015)

Modelling adalah proses pembuatan bentuk- bentuk virtual yang melengkapi suatu scene. Dan Tekstur merupakan teknik pemberian detail material pada sebuah obyek (Nugraha,2016).

Menurut Bhanu (dalam setiawan,2017) untuk menghasilkan obyek tiga dimensi yang realistis, maka dibutuhkan pembuatan tekstur dan material yang sesuai. Penggunaan pola tekstur yang sesuai akan berimplikasi pada detail obyek, kesesuaian model dengan bentuk aslinya, serta efisiensi memori dan storage komputer. Dengan menggunakan pola tekstur yang sesuai akan berpengaruh terhadap detail obyek dan kesesuaian model dengan bentuk aslinya.

Polygon adalah bentuk sisi luar (faces), ditentukan oleh titik tiga dimensi (vertices) dan garis lurus yang menghubungkan mereka (edges). Wilayah interior polygon disebut faces. Vertices edges, dan faces adalah komponen dasar dari polygon. Apabila memilih dan memodifikasi polygon yaitu menggunakan komponen dasar.(Ginanjar, 2015)

\section{METODE PENELITIAN}

Jenis penelitian yang digunakan di dalam penelitian ini adalah adalah jenis penelitian Action research atau penelitian tindakan. Menurut Guritno (dalam setiawan,2017) Action research merupakan bentuk penelitian terapan yang bertujuan untuk mencari suatu cara efektif yang menghasilkan perubahan disengaja dalam suatu lingkungan yang sebagian dikendalikan.

Metode pengumpulan data dilakukan dengan melakukan studi pustaka, observasi, dan studi kearsipan. Keggiatan analisis data menggunakan kuisioner uji kemiripan dilakukan setelah proses pemodelan dan penteksturan dari 3D candi Cetho, dan berikut adalah alur dari penelitian untuk melakukan evaluasi hasil penteksturan dari pemodelan 3D candi Cetho.

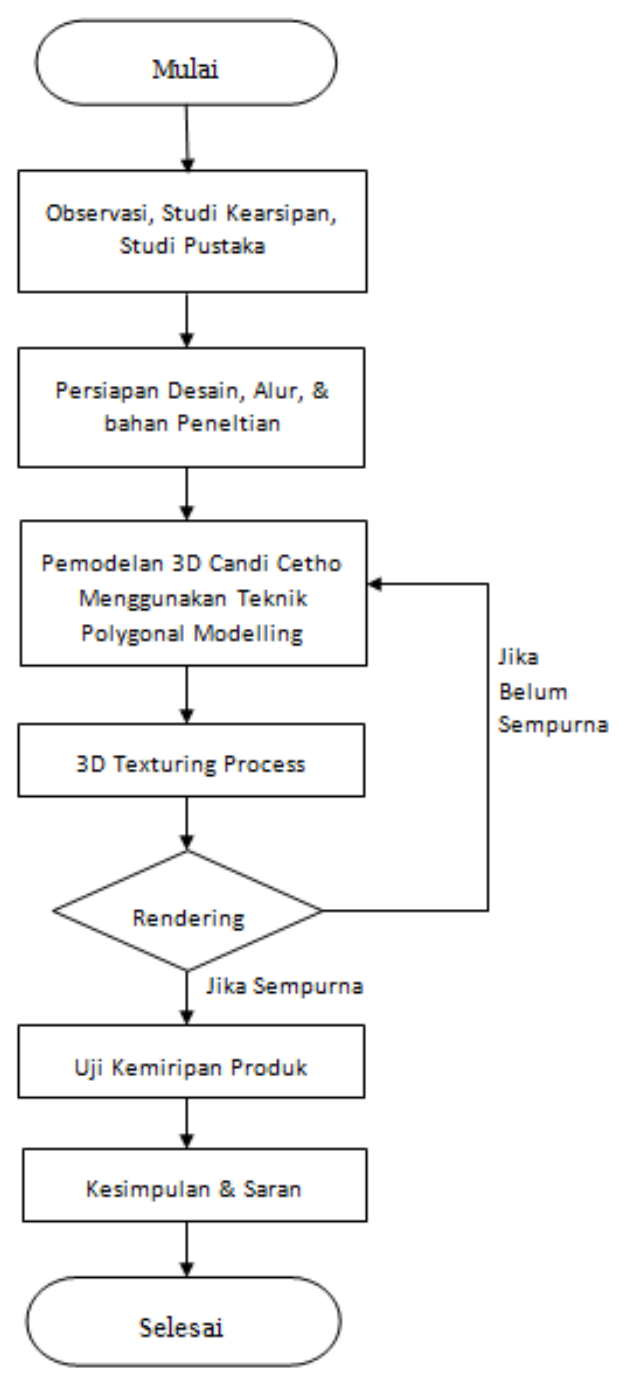

Gambar 1 Alur Penelitian

\section{HASIL DAN PEMBAHASAN}

1. Analisis Kebutuhan

Kebutuhan fungsional produk 3D yang dihasilkan mampu melakukan fungsi sebagai berikut : 
a. Produk 3D yang dibuat dapat memberikan visualisasi yang serupa dengan obyek aslinya,

b. Produk yang dibuat dapat digunakan sebagai 3D aset dalam pengembangan produk yang lebih luas.

2. Kebutuhan Non Fungsional

Analisis ini menyangkut kebutuhan perangkat keras dan perangkat lunak dimana di dalam penelitian ini spesifikasi yang digunakan adalah sebagai berikut :

a. Spesifikasi hardware yang digunakan yaitu Laptop Axioo Neon BNE dengan spesifikasi Processor AMD E2-2000 APU with Radeon(tm) HD Grapichs $1.75 \mathrm{GHz}$, RAM 2 GB, Windows 7 professional type 32-bit Operating System.

b. Spesifikasi Softwere yang digunakan yaitu Autodesk Maya 2009, Crazy Bump Versi 1.22, Adobe Photoshop cs 4, Corel Draw X3.

\section{Pemodelan 3D Candi Cetho}

\section{Berdasarkan}

proses

pengerjaannya, pembentukan obyek 3D pada Candi Cetho terbagi menjadi 6 bagian proses pengerjaan. Pemodelan tahap pertama sampai keenam memiliki kecenderungan yang sama dimulai dengan proses pemodelan yang diawali dengan bentuk bangun dasar polygon Cube. dilanjutkan melakukan proses modifikasi pada face,vertex dan edge sehingga bentuk bangun dasar tersebut dapat dibentuk sesuai dengan acuan gambar referensi.

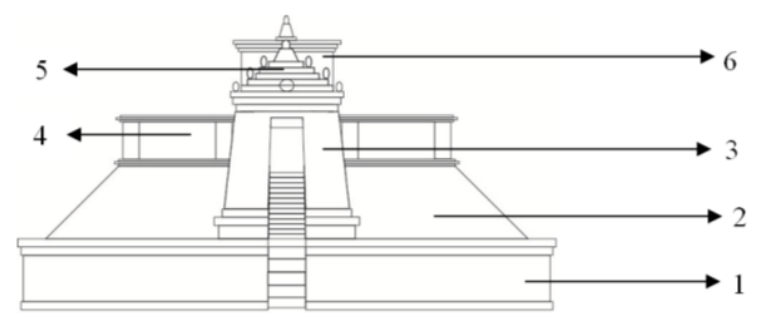

Gambar 2 Enam Bagian Proses Modeling Candi

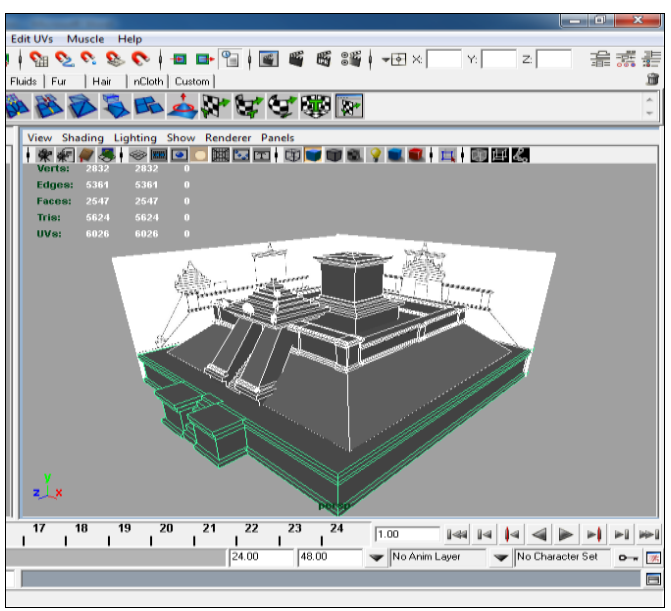

Gambar 3 Hasil Pemodelan 3D candi Cetho tanpa tekstur

4. 3D Texturing Process

Pemberian

procedural

textures dan files textures dipilih sesuai dengan kebutuhan berdasarkan penampakan secara visual dari permukaan obyek aslinya. Untuk obyek candi Cetho terdapat tekstur batuan berubin permukaan yang tidak merata pada permukaannya.(setiawan, 2017)

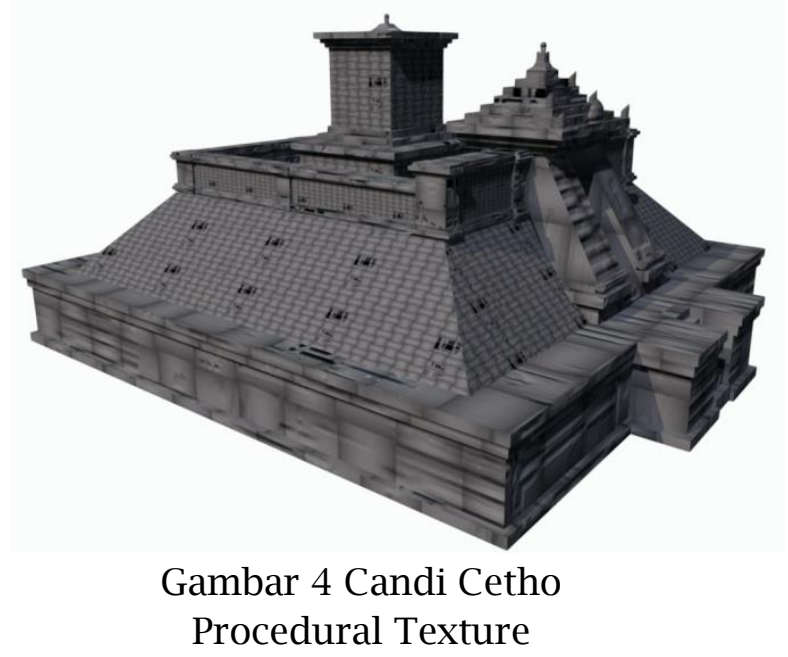

Pemberian procedural textures dan files textures dipilih sesuai dengan kebutuhan berdasarkan penampakan secara visual dari permukaan obyek aslinya. Untuk obyek candi Cetho terdapat tekstur batuan 
berubin permukaan yang tidak merata pada permukaannya.

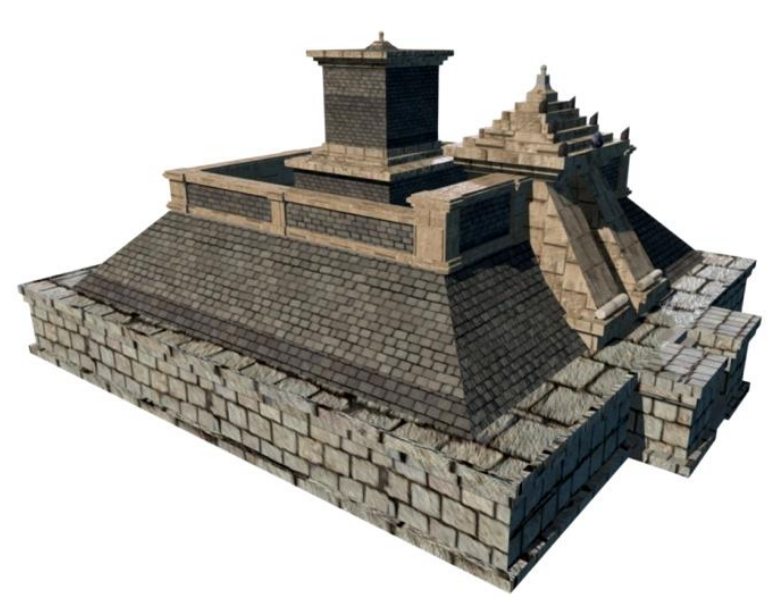

Gambar 5 Candi Cetho

Files Texture

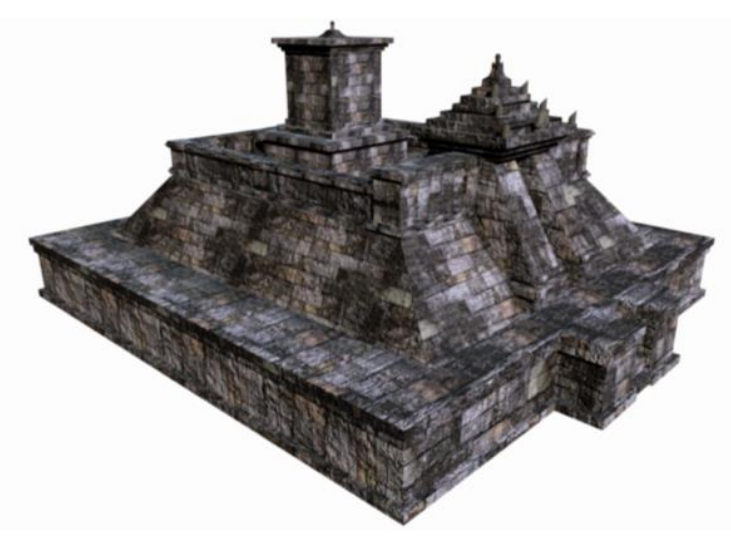

Gambar 6 Candi Cetho Files Texture Perbaikan

5. Uji kemiripan Produk 3D

Produk 3D yang sudah dibuat sudah diujikan 25 Responden. Pengujian produk menggunakan kuisoner uji kemiripan.Berdasarkan hasil penyebaran kuisioner didapat hasil sebagai berikut :
Kemiripan Model 3D candi Cetho dengan bentuk asli 25 tanggapan

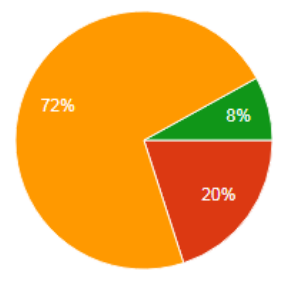

Sangat Mirip - Mirip Tidak Mirip - Sangat Tidak M

Gambar 7 Prosentase

Kemiripan dengan Files Texture

Untuk model 3D candi cetho dengan procedural texture didapatkan prosentase Sebanyak 72 \% Tidak mirip,20 \% mirip, dan 6\% sangat Tidak mirip.

Kemiripan Model 3D candi Cetho dengan bentuk asli 25 tanggapan

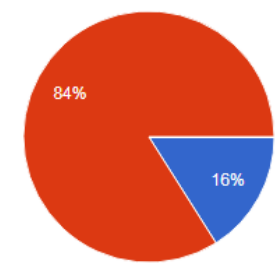

- Sangat Mirip

- Mirip

Tidak Mirip

Gambar 8 Prosentase Kemiripan dengan procedural texture

Untuk Model 3D candi cetho dengan files textures didapatkan prosentase Sebanyak $84 \%$ mirip dan $16 \%$ sangat mirip.

\section{KESIMPULAN DAN SARAN}

Berdasarkan hasil uji kemiripan dari 25 responden mengenai penteksturan dari model 3D candi cetho didapat kesimpulan sebagai berikut :

1. Untuk candi cetho dengan procedural texture didapatkan prosentase Sebanyak 72 \% Tidak mirip,20 \% mirip, dan $6 \%$ sangat Tidak mirip.

2. Untuk Model 3D candi cetho dengan files textures didapatkan prosentase Sebanyak 84 \% mirip dan 16 \% sangat mirip.

3. Mengingat ini adalah penelitian awal dan masih jauh dari kesempurnaan, maka diperlukan kajian baru tentang penggunaan kolaborasi teknik penteksturan yang lain demi 
terciptanya model 3D yang lebih realistis.

\section{DAFTAR PUSTAKA}

Ginanjar, Asep Gigin., 2015, Perancangan dan Pembuatan konsep karakter 3D robot polisi indonesia dengan Teknik render realistik menggunakan engine V-ray pada softwere 3D-maxs, Naskah publikasi, STMIK AMIKOM, Yogyakarta

Hendy, I Nyoman., 2015, Pembuatan Model 3D candi Gebang menggunakan Metode Fotogrametri Jarak Dekat, UGM, yogyakarta https://repository.ugm.ac.id/129442/

Nugraha, Bhanu Sri., 2016 Perancangan Model 3D Datacenter menggunakan Material dan Pencahayaan Vray, Jurnal Semnas, ISSN : 2302-3805, STMIK AMIKOM, Yogyakarta
Prasetyanto, Anselmus Aris Budi., 2014, Analisis dan Perancangan 3D modeling Karakter dan Backgroun Game The Hero OF Majapahit Menggunakan metode Subdivision \& digital sclupting, Naskah Publikasi, STIMK AMIKOM, Yogyakarta

Ridwan, Yusuf Budiar., 2015, Perancangan dan Pembuatan Model Sepeda Custom 3D menggunakan Teknik Polymodelling dan Vray, Naskah Publikasi, STMIK AMIKOM Yogyakarta

Setiawan, D., Suyanto, M., \& Al Fatta, H. (2017). Analisa dan Perancangan 3D Candi Cetho Menggunakan Metode Polygonal Modeling. Jurnal Ekonomi Dan Teknik Informatika, 5(9), 22-32. 